\title{
Shortspine thornyhead and rockfish (Scorpaenidae) distribution in response to substratum, biogenic structures and trawling
}

\author{
Cherisse Du Preez ${ }^{1, *}$, Verena Tunnicliffe ${ }^{2}$ \\ ${ }^{1}$ Department of Biology, University of Victoria, PO Box 3080, Victoria, British Columbia V8W 3N5, Canada \\ ${ }^{2}$ School of Earth and Ocean Sciences, University of Victoria, PO Box 3080, Victoria, British Columbia V8W 3N5, Canada
}

\begin{abstract}
Learmonth Bank in northern British Columbia sustains an active trawl fishery that returns large bycatches of deep-sea sponges and corals. To examine effects of biogenic structures on the distribution of fish, we examined nearly $30 \mathrm{~km}$ of high-definition imagery from a remotely operated vehicle and documented locations of 2770 scorpaenid fish. The 2 local genera have similar abundances, averaging about 1.2 individuals $100 \mathrm{~m}^{-2}$, but have different spatial abundance patterns: shortspine thornyhead Sebastolobus alascanus are randomly distributed on featureless substrata and their abundance increases with depth. Rockfish Sebastes spp. associate with higher seafloor relief nonrandomly and select for sponges and corals over the inert substrata alone; $95 \%$ of the rockfish occurred on $27 \%$ of the seafloor surveyed. Sponges (Demospongia and Hexactinellida) were abundant on the bedrock and boulders of the bank and adjacent moraine and covered 30 to $55 \%$ of the seafloor compared with $1 \%$ of the sediment and aggregates of the surrounding basin. The majority of rockfish $(80 \%)$ occurred with sponges $\geq 50 \mathrm{~cm}$ in height, and even beds of short sponges attracted 4 times as many rockfish than did substrata with no large epifauna. While over half of primnoid corals over $30 \mathrm{~cm}$ tall had associated rockfish, less than $2 \%$ of the seafloor had large coral, and small coral had no associated rockfish. On the adjacent seafloor with past trawling activity, Primnoa pacifica was 13 times less abundant, and large corals and sponges were rare. Thornyhead abundance doubled but rockfish had a 3-fold reduction in numbers. Our study indicates that degradation of biogenic structures is a long-term detriment to rockfish species and, although the mechanism remains unclear, our data suggest it occurs through the destruction of a habitat that is more effective for shelter than rough inert seafloor.
\end{abstract}

KEY WORDS: Scorpaenidae $\cdot$ Rockfish $\cdot$ Shortspine thornyhead $\cdot$ Biogenic structure $\cdot$ Sponge $\cdot$ Coral $\cdot$ Trawling $\cdot$ Remotely operated vehicle

\section{INTRODUCTION}

Geological and biological characteristics of the seafloor can influence benthic fish assemblage composition and abundance (Richards 1986, Krieger \& Wing 2002, Freese \& Wing 2003); however, our understanding of the functional significance of these associations remains limited (Roberts et al. 2009). High abundances of benthic fish occur with some deep-sea sponges and corals (Krieger \& Wing 2002, Freese \& Wing 2003), but it is unclear whether the associations are obligate or facultative, or whether the co-occurrence reflects similar requirements (Auster 2005, 2007). Questions regarding the ecological relevance of sponges and corals to fish populations are increasingly pertinent to fish stock management as capture fisheries grow and diversify (Morgan \& Chuenpagdee 2003). Resolution of such relationships will guide conservation decisions in areas of abundant biogenic structures. Biogenic structures are highly vulnerable to physical contact with 
trawling gear (Heifetz et al. 2009). Their recovery from trawling activity may be so slow (Andrews et al. 2002, Risk et al. 2002) that these biogenic habitats should be viewed as a nonrenewable feature.

Because deep-water research is limited by natural conditions, studies on scorpaenid fish associations with seafloor characteristics are often descriptive (Krieger $\&$ Wing 2002) or examine only 1 or 2 features of the seafloor, for example: a generalization of the habitat (Richards 1986), large-scale terrains (Yoklavich et al. 2000), substrata (Pearcy et al. 1989), corals (Husebø et al. 2002), sponges (Freese \& Wing 2003), depth and trawling activity (Hixon \& Tissot 2007). Our study includes all these factors and attempts to control for their confounding interrelationships to separate the specific effects of sponges and corals on the scorpaenid fish assemblage. This approach also enabled us to follow Auster's (2005) suggestion to compare biogenic habitats with other habitats.

Benthic fish must contend with bottom currents and avoid downstream displacement from preferred habitats by station-holding (Webb 1989). Because stationholding by swimming is energetically expensive, a more effective strategy is for fish to reduce form drag by finding refuge in a location with lower flow velocity (Webb 1989). There are 2 basic morphologies of benthic fish (Bone \& Marshall 1982): flattened and fusiform. A flattened morphology facilitates stationholding by allowing the fish to hide within the boundary layer against the seafloor (Arnold \& Weihs 1978); this shape is an adaptation for inhabiting featureless seafloors (Allen et al. 2006). Structures on the seafloor modulate the local flow regime and provide areas of reduced currents where fusiform fish can take refuge. Auster (2007) suggests geological and biological habitats are functionally equivalent as fish flow refuge. In the present study, we investigate fish selection for sponge and coral biogenic structures over inert abiotic structures alone.

British Columbia's Learmonth Bank area is regarded as a 'hotspot' for demersal fish trawling activity (Sinclair et al. 2005) and the 2 local scorpaenid genera are common in catches (Fisheries and Oceans Canada 2010). Reports of coral/sponge bycatch here are among the highest amounts on British Columbia's continental shelf and have led to consideration of the area for protection (Ardron et al. 2007). Ardron et al. (2007) suggest that in situ studies measuring the actual effects of trawling are the only true indicator of the ecological benefits of the proposed closure. It is usually difficult to examine effects of trawling because areas of similar environmental conditions and accessibility adjacent to a trawled area rarely remain untrawled (Sinclair et al. 2005). Nonetheless, such conditions still exist in Learmonth Bank as a consequence of an unresolved mar- itime boundary dispute between Canada and the USA (Gray 1997), providing a unique opportunity to compare very similar trawled and untrawled coral habitats.

This study uses in situ imagery to examine the seafloor factors that influence scorpaenid fish abundance patterns controlling for the confounding interrelationships. A major objective is to determine the nature of both a scorpaenid fish assemblage and the benthic biotopes. In addition, we examine 3 hypotheses: (1) shortspine thornyhead Sebastolobus alascanus and rockfish Sebastes spp. distribution patterns are markedly different with respect to seafloor relief; (2) the abrupt vertical relief of large biogenic structures attracts rockfish in a facultative association over the relief of inert substrate alone; and (3) degradation of biogenic structures such as corals by trawling has direct consequences on rockfish abundance and distribution patterns.

\section{MATERIALS AND METHODS}

Study area. Learmonth Bank spans $\sim 37 \mathrm{~km}$ across the opening of Dixon Entrance, north of Haida G'wai, British Columbia, Canada (54² 24' 59" N, 133 05' 00" W; Fig. 1). This submerged granite massif is surrounded by glacial till largely composed of mud and sand (Bornhold \& Barrie 1991, Barrie \& Conway 1999). Scattered erratic boulders and the rugged topography reflect the region's glaciated periods when the sea level was $150 \mathrm{~m}$ lower than it is now and the bank was exposed to glacial erosion and iceberg scour (Bornhold \& Barrie 1991, Barrie \& Conway 1999, 2002).

Dixon Entrance opens onto the continental shelf with a high wave exposure and open ocean swells (fetch $>500 \mathrm{~km}$ ). Strong freshwater inputs from mainland rivers drive an estuarine circulation through Dixon Entrance with a northwestward surface outflow and an eastward bottom inflow (Zacharias et al. 1998). Owing to its transverse orientation and rise from $\sim 400$ to 50 m depth, Learmonth Bank is a submarine barrier that, through the processes of tidal rectification and density forcing, is encircled by a clockwise eddy (Crawford \& Greisman 1987, Ballantyne et al. 1996). These geologic and oceanographic features could facilitate food trapping, detritus falls and vertical migration of zooplankton that may contribute to the high abundance of fish (Sinclair et al. 2005).

Field work. In July 2008, a remotely operated vehicle (ROV 'ROPOS') executed 5 dives on and around Learmonth Bank, all above $500 \mathrm{~m}$ depth. The ROV flew 32 transects (Fig. 1, Table 1), ranging between 0.55 and $1.05 \mathrm{~km}$ long, at average speeds between 0.5 to 1 knots and 0.5 to $1 \mathrm{~m}$ off the seafloor. In total, we collected data from $29.2 \mathrm{~km}$ of transects (average 


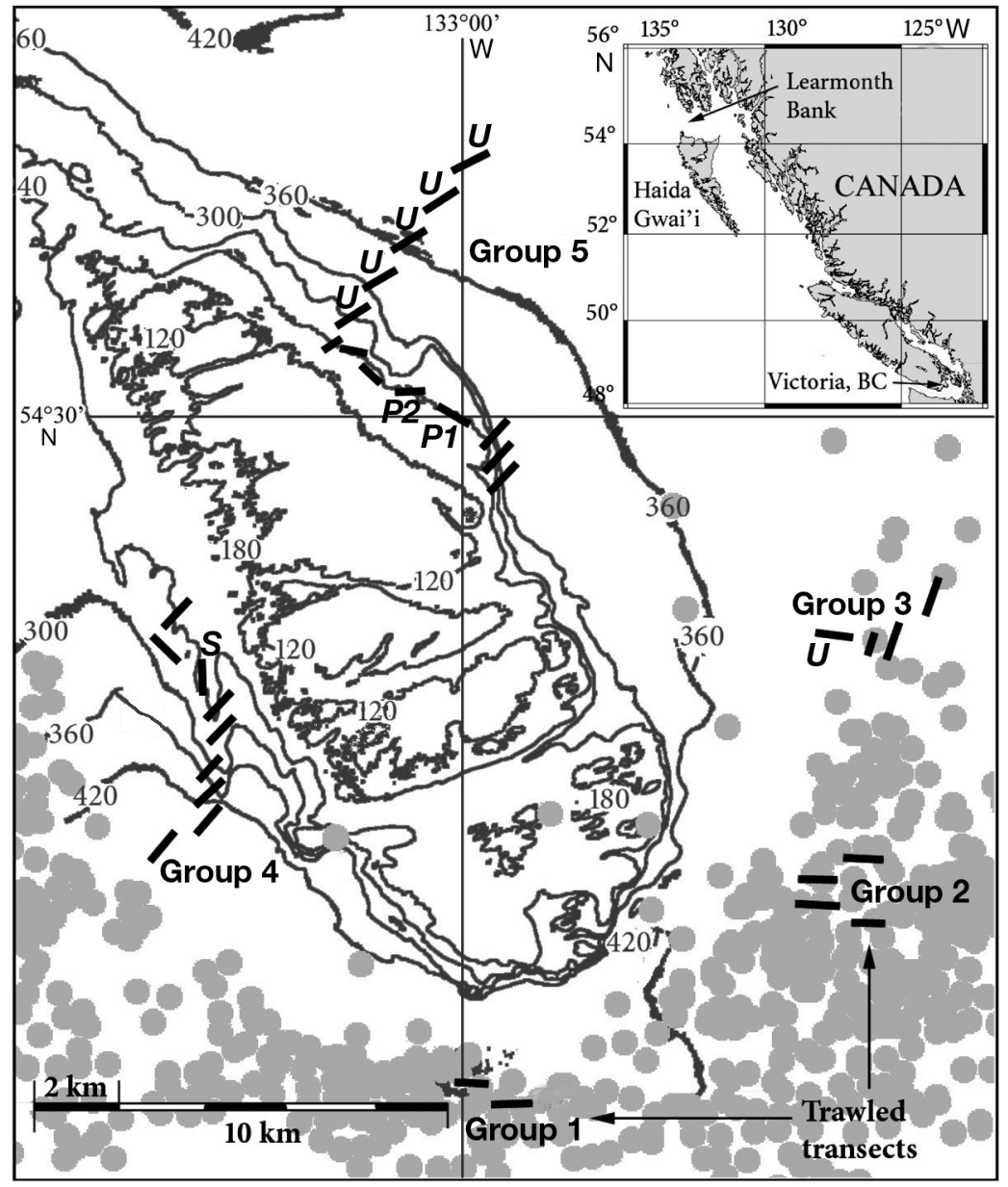

Fig. 1. Bathymetry $(\mathrm{m})$ of Learmonth Bank with locations of ROV transects (black lines, in 2008) and commercial trawl sets (grey circles, from 2002 to 2007). Inset shows location of study area off the coast of British Columbia. Six transects were made in trawled areas (Groups 1 and 2) and 26 in untrawled areas. Trawling does not occur north of $54^{\circ} 30^{\prime}$ because of an unresolved boundary dispute in this area. Labeled transects: $(U) 6$ untrawled transects used for comparisons (see 'Materials and methods: Data analysis'); (P1) highest and (P2) second highest abundances of Primnoa pacifica; and $(S)$ largest patch of Tall sponge gardens (see Table 2 for definition) and highest abundance of rockfish. Map is adapted from multibeam bathymetry and Fisheries and Oceans Canada summary groundfishery records for 2002 to 2007 in Dixon Entrance (courtesy of J. V. Barrie and J. Boutillier)

swath, $4 \mathrm{~m}$ wide) with imagery from high definition (HD) video recordings. The HD video camera (Zeus Plus, Insite Pacific) was mounted facing forward to provide continuous recording of a constant field of view that included 2 parallel laser points projected $10 \mathrm{~cm}$ apart for scale.

Dive sites were selected to sample within the 3 seascapes of Learmonth Bank (Fig. 1, Table 2): the bank itself (8 southern transects in Group 5), the western moraine ( 7 northern transects in Group 4) and the basin areas (remaining transects). Fisheries and Oceans Canada summary of groundfishery records for 2002-2007 in Dixon Entrance assisted in identifying areas of trawl activity around Learmonth Bank. A transect's 'trawl status' was confirmed by blind-testing for trawl evidence in the video recording without prior knowledge of trawl records. Visual evidence included trawl scars, door and roller marks, pinned nets (Fig. 2A) and dragged or overturned boulders. The presence or absence of trawl scars in $100 \mathrm{~m}$ range sonar scans, taken from the ROV every $250 \mathrm{~m}$, provided further confirmation of a transect's trawl status. Six 'Trawled' transects were identified (Groups 1 and 2 in Fig. 1).

Video recording analysis. Position (ROV 'ROPOS' accuracy: $\pm 1 \%$ of water depth) and imagery information was transferred to a relational database linked by time stamps. Forty-six hours of transecting was parsed into more than 230000 records. A record represents non-overlapping seafloor observed during 1 to $2 \mathrm{~s}$ of transecting (averaging 1 to $2 \mathrm{~m}^{2}$ of seafloor per record). Several thousand records in serial succession describe the length of a transect. Biological and geological features (some after Sameoto et al. 2008) were annotated for each record and included substratum (as percent cover of 6 sediment types), epifauna cover (i.e. sponges and coral; Fig. 2B,C), scorpaenid fish identity (Fig. 2B-D) and events of interest (e.g. trawl evidence; Fig. 2A). The distribution of substratum type and epifauna cover over the 3123 records in a single transect is illustrated in Fig. 3. Other information included the ROV's survey mode and the camera's field of view (Sameoto et al. 2008). Species identification from imagery can be difficult. Sponges can be particularly problematic; thus, we used a high taxonomic level in this study to identify all to the same taxonomic level. Size of fauna was estimated by using the projected laser scale as a guide.

We used a classification scheme to characterise the seafloor's bottom roughness for each record (Table 2) with 3 parameters: seascape, substratum type and epifauna cover. Each has a hierarchy of 3 to 4 mutually exclusive categories relating to bottom roughness. Vertical relief at the scale of the parameter is a proxy for bottom roughness, where topography determines 'seascape' at a scale of tens to hundreds of metres, sediment size based on the Wentworth scale determines 
Table 1. Distribution of observations among the seascapes including occurrences of substratum types and epifauna types (see Table 2 for definitions of seascape, substratum and epifauna types)

\begin{tabular}{|lcccc|}
\hline & Trawled (in Basin) & Basin & Moraine & Bank \\
\hline Number of transects & 6 & 11 & 7 & 8 \\
Total transect length $(\mathrm{m})$ & 5600 & 10250 & 7050 & 6300 \\
No. of transect records & 23177 & 45548 & 32888 & 27963 \\
Average $( \pm$ SE) depth $(\mathrm{m})$ & $419 \pm 19$ & $377 \pm 15$ & $278 \pm 20$ & $234 \pm 20$ \\
Average $\left( \pm\right.$ SE) surveyed surface area $\left(\mathrm{m}^{2}\right)$ & $3578 \pm 260$ & $3509 \pm 272$ & $4756 \pm 349$ & $3809 \pm 453$ \\
Average \% surface area $( \pm$ SE) of substratum type & & & \\
$\quad$ Sand & $18.8 \pm 6.1$ & $64.2 \pm 8.7$ & $37.5 \pm 6.9$ & $30.2 \pm 8.4$ \\
$\quad$ Aggregates & $58.3 \pm 9.2$ & $24.9 \pm 7.9$ & $27.6 \pm 5.3$ & $23.4 \pm 7.9$ \\
$\quad$ Boulder/bedrock & $22.9 \pm 7.4$ & $10.9 \pm 5.3$ & $34.9 \pm 4.4$ & $46.4 \pm 4.7$ \\
Average \% surface area $( \pm$ SE) of epifauna cover & & & & \\
$\quad$ Epifauna absent & $81.2 \pm 14.7$ & $98.8 \pm 1.0$ & $67.5 \pm 9.5$ & $40.7 \pm 8.1$ \\
Short sponge gardens & $18.5 \pm 14.5$ & $0.9 \pm 0.9$ & $8.3 \pm 3.6$ & $22.5 \pm 4.0$ \\
Tall sponge gardens & $0.2 \pm 0.2$ & $0.2 \pm 0.1$ & $24.2 \pm 7.6$ & $32.0 \pm 5.6$ \\
Coral stands & $0.0 \pm 0.0$ & $0.1 \pm 0.1$ & $0.1 \pm 0.1$ & $4.8 \pm 3.3$ \\
\hline
\end{tabular}

Table 2. Each of the 230000 records was classified within a seascape, substratum type and epifauna cover category. The possible combinations result in 12 mutually exclusive biotopes for each seascape. Within a classification categories are listed in order of low to high relief

\begin{tabular}{|c|c|}
\hline Classification/ category & Description \\
\hline Seascape & $\begin{array}{l}\text { Large-scale context of a record based on location with regards to geological } \\
\text { features, depth and topography }\end{array}$ \\
\hline Basin & Deepest seascape: generally flat and uniform \\
\hline Moraine & $\begin{array}{l}\text { Sinuous feature with gradual slopes composed of large-scale mounds of coarse } \\
\text { sediment }\end{array}$ \\
\hline Bank & $\begin{array}{l}\text { Shallowest and most heterogeneous with seafloor orientation ranging from flat } \\
\text { plateaus to } \sim 300 \text { m cliffs }\end{array}$ \\
\hline Substratum type & $\begin{array}{l}\text { Substratum classification based on percent cover of surficial sediment types per } \\
\text { record }\end{array}$ \\
\hline Sand (Snd) & Fine and unconsolidated; sediment composed of $\geq 90 \%$ sand (Fig. 2D) \\
\hline Aggregates (Agg) & $\begin{array}{l}\text { Mainly aggregates (pebble and cobble); sediment composed of < }<0 \% \text { sand, } 5 \% \\
\text { boulder and no bedrock }\end{array}$ \\
\hline Boulder/bedrock (Bol) & Hard substratum prevalent; $>5 \%$ boulder and/or bedrock present (Fig. $2 \mathrm{C}$ ) \\
\hline Epifauna cover & $\begin{array}{l}\text { Biological classification based on composition, density and height of epifauna } \\
\text { per record }\end{array}$ \\
\hline Epifauna absent (EA) & $\begin{array}{l}\text { Bare substratum (Fig. 2D) or small epifaunal organisms attached with short erect } \\
\text { sponges; }<3 \text { ind. } \mathrm{m}^{-2}\end{array}$ \\
\hline \multicolumn{2}{|l|}{ Epifauna present (EP) } \\
\hline Sponge gardens: & Community of Demospongia and/or Hexactinellida: \\
\hline Short sponge gardens (SSG) & Dense short erect sponge cover; $\geq 3$ ind. $\mathrm{m}^{-2}$ \\
\hline Tall sponge gardens (TSG) & Tall erect sponge $; \geq 1$ ind. $\mathrm{m}^{-2}$ (Fig. $2 \mathrm{~B}$ ) \\
\hline Coral stands (CS) & Tall Primnoa pacifica $\geq 1$ ind. $2 \mathrm{~m}^{-2}$ (Fig. $2 \mathrm{C}$ ) \\
\hline
\end{tabular}

'substratum type' at a scale of centimetres and organism type and height determines 'epifauna cover' at a scale of centimetres. The combination of substratum type and epifauna cover produces 12 biotopes for each seascape (Table 2).

The epifauna cover category Epifauna absent (EA) includes bare substratum (Fig. 2D) and substratum with small epifaunal organisms attached, for example encrusting sponges, Stylaster and hydroids; we focussed only on larger epifauna. The categories Short sponge gardens (SSG) and Tall sponge gardens (TSG) are not defined by specific species (Table 2). The majority of short sponges (between 10 and $50 \mathrm{~cm}$ ) were Demospongia, while the majority of tall sponges $(\geq 50 \mathrm{~cm})$ were Hexactinellida with a few Demospongia. Red tree coral Primnoa pacifica height categories are short (between 10 and $30 \mathrm{~cm}$ ) and tall $(\geq 30 \mathrm{~cm})$. Owing to the small size and limited abundance of other coral species, only tall $P$. pacifica (Fig. 2C) defines the category coral stands (CS; Table 2$)$. 

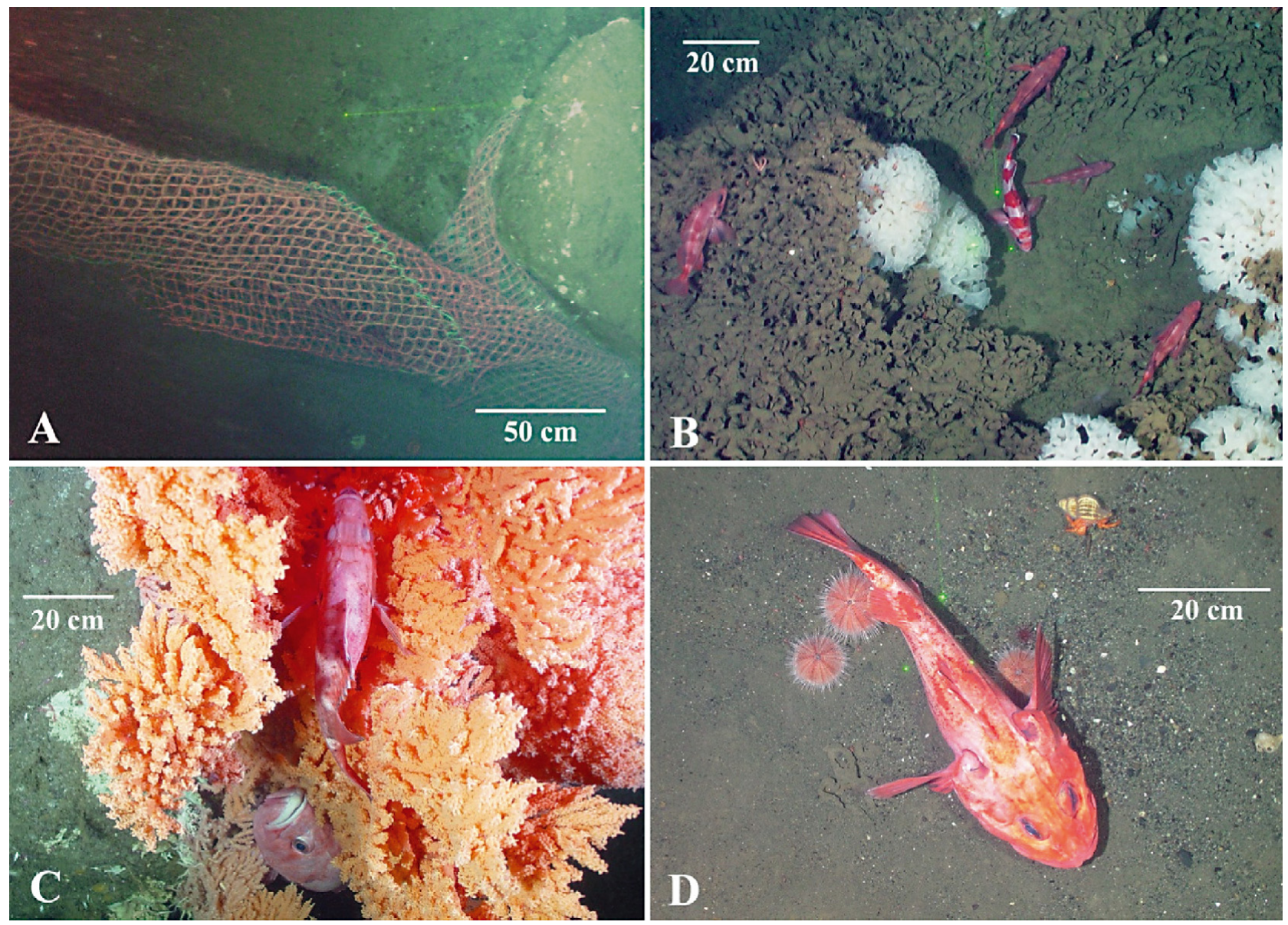

Fig. 2. (A) A piece of bottom trawling net pinned beneath an overturned boulder showing evidence the large boulder was dragged $>10 \mathrm{~m}$ before breaking free; such observations confirmed the trawled status of a transect. (B) Four sharpchin rockfish and a redbanded rockfish among mounds of a Farrea occa sponge; record type is Tall sponge garden on Boulder. (C) Two shortraker rockfish between the branches of Primnoa pacifica; record type is Coral stand on Boulder. (D) Large shortspine thornyhead on sand; record type is Epifauna absent on Sand. Images were taken with ROV 'ROPOS'. See Table 2 for definitions of record types

Two genera of scorpaenid fish occur at Learmonth Bank, thornyhead Sebastolobus and rockfish Sebastes. Scorpaenid fish were classified to the lowest taxonomic level possible (Table 3) and their physical association with bottom features was recorded. Within this study 'association' is defined as from close proximity $(\leq 10 \mathrm{~cm})$ to full contact (most observations) with the structure.

Data analysis. All data annotated from the video analysis were entered into an ACCESS database to support subsequent queries. Using the size of the camera's footprint and the location of the record, percent coverage of record attributes and discrete counts produced estimates of seafloor surface area and density measurements. Densities were standardised to $100 \mathrm{~m}^{2}$ or to the average surveyed area of transects, $4000 \mathrm{~m}^{2}$. All analyses, except the comparison between Trawled (Tr) and Untrawled (UTr), excluded the 6 Tr transects and, therefore, $\mathrm{n}_{\max }=26$ transects. For all analyses, transects were used as replicates and averages reported with SE. A minimum of 5 transect replicates were required to run a statistical test. CS represented only $<2 \%$ of the surveyed area resulting in low statistical power for analyses with CS biotopes.

We used PASW Statistics 18 software for our statistical analyses. The variance:mean ratio (VMR), an index of dispersal, was used to determine a species distribution pattern over the 26 untrawled transects, where $\mathrm{VMR}=1$ indicates a species has a random distribution, and $\mathrm{VMR}<1$ and VMR $>1$ suggest even and clumped distributions, respectively. A Mann-Whitney $U$-test determined significance of the difference between the VMR and a value of 1 . To investigate interdependence between scorpaenid fish abundances and seafloor variables, we used Pearson correlations. Within the correlation matrix, we included depth, one category to represent the substratum type, Boulder/bedrock (Bol), and one category to represent the epifauna cover, 


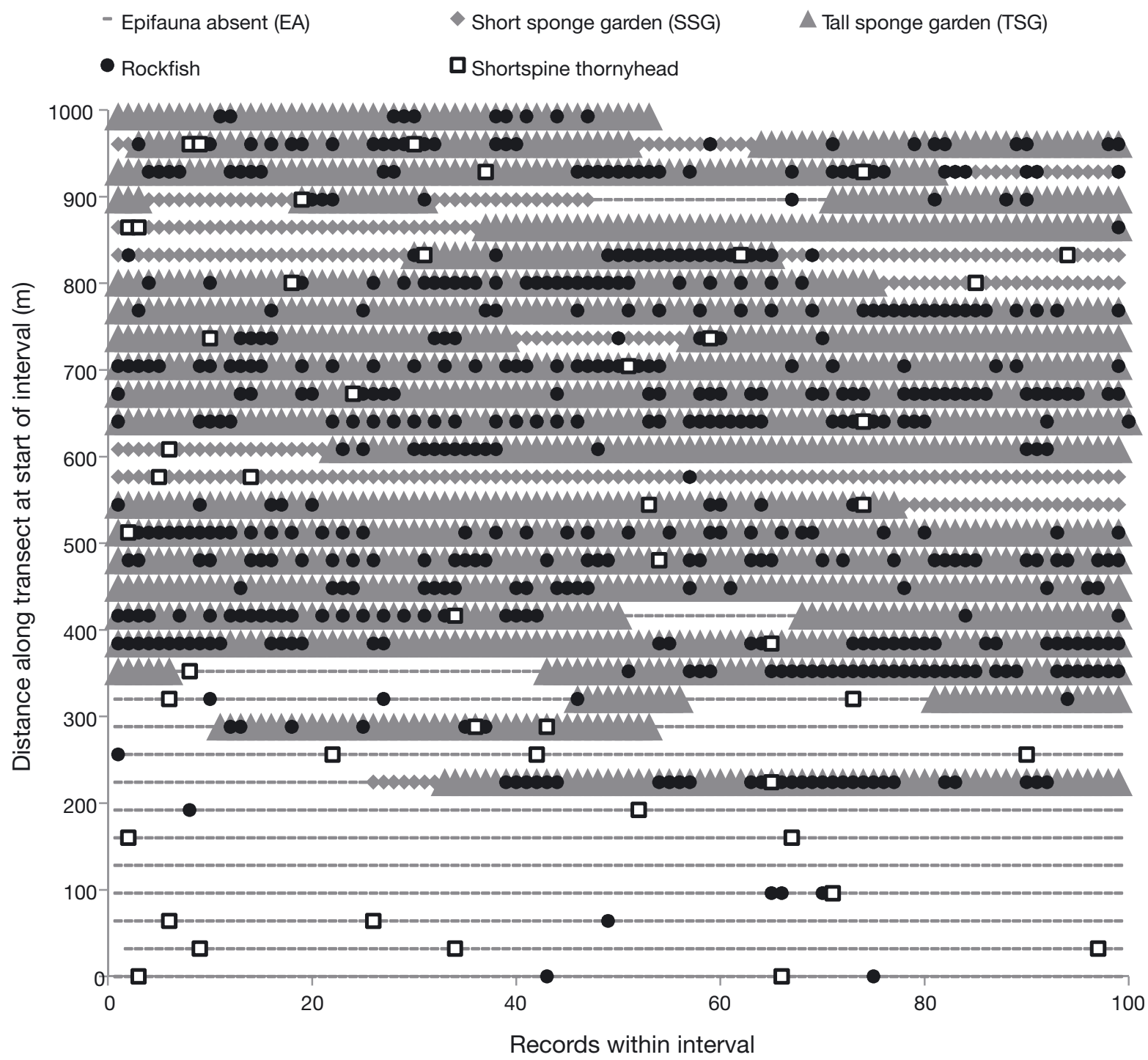

Fig. 3. Example of observations along a $1 \mathrm{~km}$ transect. The 3123 non-overlapping records describe the epifauna cover and scorpaenid fish distribution for a moraine transect (' $S$ ' in Fig. 1). Transect begins at lower left of the figure and continues in a straight line although it is broken into stacked 'intervals' to display here. Each record represents $\pm 0.33 \mathrm{~m}$ along the transect. The figure illustrates the random distribution of shortspine thornyheads compared with the clumped distribution of rockfish associating with 'Tall sponge gardens'

Epifauna present (EP). To resolve for independent relationships influencing thornyhead and rockfish abundance patterns, we used partial correlations (Table 4) and stepwise multiple regressions (Else et al. 2002). Variables for the correlation matrices were $\log (y+1)$ transformed to normalize ( $\mathrm{n}=15$ Moraine and Bank transects; Basin transects had too many null values for the variables to be included). To investigate the independent response of scorpaenid abundance to the presence of large sponges and corals, we controlled for substratum type in each epifauna cover category. For this analysis, all biotopes had to occur on the transect to reduce variation among transects; biotope comparisons were of patches of the seafloor located on the same transect. Thus, we can identify rockfish interactions specifically with biogenic structures rather than just recording fish co-occurrence with biogenic structures and their substrata. To test scorpaenid response to substratum type and epifauna cover separately, we used $t$-test, Mann-Whitney $U$-test, ANOVA and Kruskal-Wallis approaches.

To select comparable untrawled transects for the 6 trawled transects, we considered location and proximity to other seascapes, percent cover of Bol and depths (Table 5). Six UTr transects (' $U$ ' in Fig. 1) were comparable with the 6 Tr transects. All 12 transects are within the Basin. Between the Tr and UTr transects, there 
Table 3. Distribution of scorpaenid fish species among the seascapes. Overall abundances and rockfish species richness include only untrawled transects $(n=26)$. While nearly equal numbers of the 2 genera were observed, there are differences in their distributions

\begin{tabular}{|c|c|c|c|c|c|c|}
\hline & Taxon & Trawled (in Basin) & Basin & Moraine & Bank & Total \\
\hline Shortspine thornyhead & Sebastolobus alascanus & 262 & 270 & 516 & 309 & 1357 \\
\hline All rockfish & Sebastes spp. & 9 & 40 & 787 & 577 & 1413 \\
\hline Sharpchin & S. zacentrus & 1 & 4 & 680 & 443 & 1128 \\
\hline Rosethorn & S. helvomaculatus & 0 & 0 & 77 & 83 & 160 \\
\hline Rougheye & S. aleutianus & 4 & 20 & 9 & 6 & 39 \\
\hline Redbanded & S. babcocki & 1 & 7 & 8 & 13 & 29 \\
\hline Silvergray & S. brevispinis & 0 & 0 & 5 & 13 & 18 \\
\hline Shortraker & S. borealis & 0 & 3 & 1 & 3 & 7 \\
\hline Redstripe & S. proriger & 0 & 0 & 0 & 7 & 7 \\
\hline Bacaccio & S. paucispinis & 0 & 0 & 1 & 3 & 4 \\
\hline Yelloweye & S. ruberrimus & 0 & 2 & 0 & 0 & 2 \\
\hline Unidentified & & 3 & 4 & 6 & 6 & 19 \\
\hline Unidentified scorpaenid fish & & 9 & 14 & 75 & 103 & 201 \\
\hline \multicolumn{7}{|c|}{ Average abundance (no. per $100 \mathrm{~m}^{2} \pm \mathrm{SE}$ ): } \\
\hline Thornyhead & Sebastolobus alascanus & $1.2 \pm 0.2$ & $0.7 \pm 0.2$ & $1.7 \pm 0.4$ & $1.1 \pm 0.3$ & $1.1 \pm 0.2^{\mathrm{a}}$ \\
\hline Rockfish & Sebastes spp. & $<0.1 \pm 0.0$ & $0.1 \pm 0.0$ & $2.1 \pm 1.4$ & $2.2 \pm 0.7$ & $1.3 \pm 0.5^{\mathrm{a}}$ \\
\hline \multirow{2}{*}{\multicolumn{2}{|c|}{$\begin{array}{l}\text { Rockfish species richness (no. species) } \\
\text { No. of transects }\end{array}$}} & 3 & 5 & 7 & 8 & 9 \\
\hline & & 6 & 11 & 7 & 8 & 32 \\
\hline \multicolumn{7}{|l|}{${ }^{\mathrm{a}}$ Trawled (in Basin) transects excluded } \\
\hline
\end{tabular}

Table 4. Pearson pairwise correlation (lower left) and partial correlation (upper right) matrices for thornyhead and rockfish abundance (ind. per $100 \mathrm{~m}^{2}$ ), depth and percent surface area of Boulder/bedrock and Epifauna present $(\mathrm{n}=15$ transects). Significant correlations are in bold text $(\mathrm{p}<0.05)$

\begin{tabular}{|lccccc|}
\hline & $\begin{array}{c}\text { Thorny- } \\
\text { head }\end{array}$ & Rockfish & Depth & $\begin{array}{r}\text { Boulder/ } \\
\text { bedrock }\end{array}$ & $\begin{array}{r}\text { Epifauna } \\
\text { present }\end{array}$ \\
\hline Thornyhead & & -0.03 & $\mathbf{0 . 5 7}$ & -0.33 & 0.20 \\
Rockfish & $\mathbf{- 0 . 6 8}$ & & 0.07 & 0.14 & 0.49 \\
Depth & $\mathbf{0 . 8 3}$ & $\mathbf{- 0 . 7 9}$ & & 0.45 & $\mathbf{- 0 . 7 6}$ \\
Boulder/bedrock & $\mathbf{- 0 . 6 3}$ & $\mathbf{0 . 7 3}$ & $\mathbf{- 0 . 6 1}$ & & 0.51 \\
Epifauna present & $\mathbf{- 0 . 7 7}$ & $\mathbf{0 . 8 9}$ & $\mathbf{- 0 . 9 2}$ & $\mathbf{0 . 7 6}$ & \\
\hline
\end{tabular}

Table 5. Descriptors of the 6 Trawled and 6 comparable Untrawled transects (seascape $=$ Basin for both) and their average abundances of Primnoa pacifica, thornyhead and rockfish. p-value indicates significance of difference between treatments, significant $p$-values are in bold text $(p<0.05)$. Transect locations indicated in Fig. 1

\begin{tabular}{|c|c|c|c|}
\hline & Trawled & Untrawled & p-value \\
\hline Total transect length (m) & 5600 & 5700 & \\
\hline $\begin{array}{l}\text { Average }( \pm \mathrm{SE}) \text { occurrence of } \\
\text { trawl evidence }\end{array}$ & $15 \pm 3$ & $0 \pm 0$ & $\ll 0.01^{\mathrm{a}}$ \\
\hline Average depth (m) & $419 \pm 19$ & $354 \pm 22$ & $0.03^{\mathrm{a}}$ \\
\hline Depth range (m) & 382 to 486 & 238 to 402 & \\
\hline $\begin{array}{l}\text { Average \% surface area of } \\
\text { Boulder/bedrock }\end{array}$ & $22.9 \pm 7.4$ & $18.0 \pm 9.0$ & $0.34^{\mathrm{a}}$ \\
\hline \multicolumn{4}{|l|}{ Abundance (no. per $100 \mathrm{~m}^{2}$ ) of: } \\
\hline Primnoa pacifica & $0.03 \pm 0.03$ & $0.4 \pm 0.18$ & $0.01^{\mathrm{a}}$ \\
\hline Thornyhead & $1.23 \pm 0.23$ & $0.63 \pm 0.15$ & $0.03^{b}$ \\
\hline Rockfish & $0.05 \pm 0.03$ & $0.18 \pm 0.05$ & $0.03^{b}$ \\
\hline$\%$ of rockfish within Coral stands & 0 & 33 & \\
\hline${ }^{\mathrm{a}}$ Mann-Whitney $U$-test ${ }_{i}{ }^{\mathrm{b}} t$-test & & & \\
\hline
\end{tabular}

was no significant difference in percent surface area comprising Bol (see Results). Although there was a difference in the average depths, the depth ranges overlapped substantially and lay within ranges known for all study organisms (Love et al. 2002, Lamb \& Hanby 2005).

\section{RESULTS}

\section{Scorpaenid fish assemblage}

Three orders dominated the demersal fish of Learmonth Bank: the Scorpaeniformes (rockfishes and thornyheads) represented $78 \%$ of the fish observed, the Pleuronectiformes (flatfishes) $12 \%$ and the Rajiformes (skates) $5 \%$. A total of 2963 scorpaenid fish were encountered, of which half were shortspine thornyhead (Fig. 2D), and the remainder were rockfish (Fig. 2B,C, Table 3). Although 9 species of rockfish were observed (Table 3), $>80 \%$ were sharpchin rockfish Sebastes zacentrus (Fig. 2B). There was no significant difference between thornyhead and rockfish overall densities (Mann-Whitney $U$-test: $\mathrm{p}=0.06, \mathrm{n}=$ 26 ; Table 3). The 2 genera showed dif- 
ferent distribution patterns $(\mathrm{n}=26)$ : thornyhead had a random distribution (VMR = $1.0 \pm 0.1$; Mann-Whitney $U$-test: $\mathrm{p}=0.127$ ), while rockfish had a clumped distribution $(\mathrm{VMR}=149.6 \pm 87.5$; Mann-Whitney $U$-test: $\mathrm{p} \ll 0.01)$.

Thornyhead and rockfish displayed distinctly different behaviours. Thornyhead usually adopted a stationary position in full contact with flat seafloor (Fig. 2D). Rockfish were usually quiescent beside or within erect structures (Fig. 2B,C), but over flat seafloor they were swimming or moved passively with the current. No schooling behaviour occurred among the scorpaenids although several rockfish could aggregate around the same structure.

\section{Seafloor effects on scorpaenid distribution}

The correlation matrix indicated that variances of both thornyhead and rockfish abundances were interrelated with all the seafloor variables listed in Table 4, including the other scorpaenid species abundance; however, the partial correlation matrix indicated only a couple of pairings of variables had significant independent relationships (Table 4).

\section{Seascapes}

Within the study area of Learmonth Bank, there were 3 distinct terrains, or seascapes (Table 2). The
Basin was largely flat and sandy with sparsely scattered erratic boulders. The seafloor slope and sediment size increased near the Bank and gave way to deeply incised walls that rose $\sim 300 \mathrm{~m}$. At $\sim 200 \mathrm{~m}$ depth, the Bank plateaued and bedrock was scattered with boulders and pockets of sediment. Below the southwestern flank of the Bank lay a sinuous Moraine, a glacial feature of mixed sediments, about $\sim 5 \mathrm{~km}$ long with relief of tens of metres. The 3 seascapes showed distinct characteristics with significantly different average seafloor depths (Kruskal-Wallis test: $\mathrm{p} \ll 0.01$; all significantly different; Table 1) and average percent surface area comprising Bol (Kruskal-Wallis test: $\mathrm{p} \ll$ 0.01; all significantly different; Table 1 ). Thornyhead density was lowest in the Basin, but still nearly 7 times higher than that of rockfish, and highest on the Moraine (Mann-Whitney $U$-test: $p=0.01$; Table 3 ). Rockfish density was an order of magnitude higher on the Moraine and Bank compared with the Basin (Mann-Whitney $U$-test: both $\mathrm{p} \ll 0.01$; Table 3 ) and rockfish species diversity was lowest in the Basin (Table 3).

\section{Substratum}

Within the surveyed area, Sand (Snd) was the most abundant substratum type and averaged $41.4 \pm 5.0 \%$ of each transect's surface area (overall, $\sim 50330 \mathrm{~m}^{2}$ ), while Aggregates (Agg) and Bol averaged $31.1 \pm 4.2 \%$ (mean $\pm \mathrm{SE}$ ) and $27.5 \pm 3.5 \%$, respectively (Fig. 4).

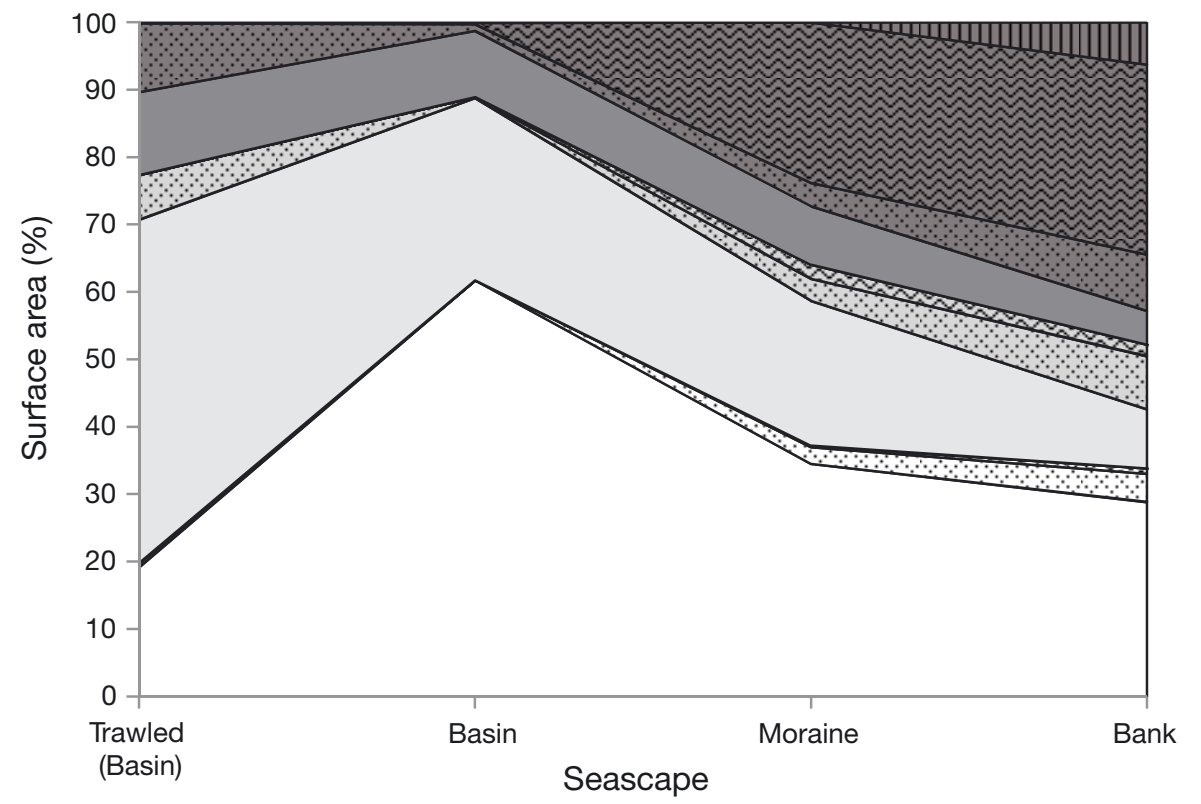

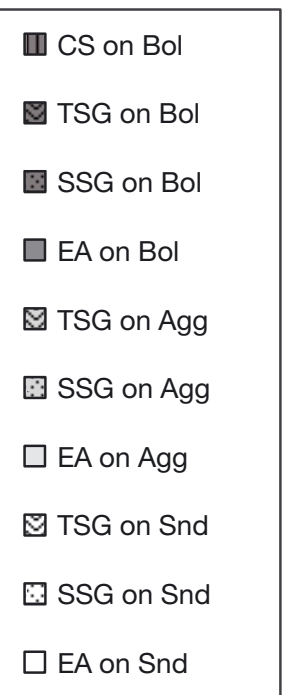

$\square$ EA on Snd

Fig. 4. Distribution of biotopes along transects of Learmonth Bank seascapes. CS: Coral stands, TSG: Tall sponge gardens, SSG: Short sponge gardens, EA: Epifauna absent; Bol: Boulder/bedrock, Agg: Aggregates, Snd: Sand (see Tables 1 \& 2). Epifauna absent on Sand was the most abundant biotope at $\sim 8200 \mathrm{~m}^{2}$ over 32 transects. Coral stands on both Sand and Aggregates occurred only in the Basin (proportions too low to show here) 
Bedrock made up the majority of the hard substratum of the Bank, whereas boulders were the only hard substratum in the Basin and on the Moraine. Boulders ( $~ 0.25$ to $1.50 \mathrm{~m}$ in diameter) tended to be dispersed rather than aggregated and added marked large-scale roughness to the seafloor, over both sediment and bedrock.

Overall, thornyhead abundance did not vary with substratum type: $0.8 \pm 0.1,1.3 \pm 0.3$ and $1.6 \pm 0.4$ ind. $100 \mathrm{~m}^{-2}$ on Snd, Agg and Bol, respectively (KruskalWallis test: $\mathrm{p}=0.61, \mathrm{n}=26$ ). The partial correlation matrix indicated that their abundance primarily had a positive correlation with seafloor depth (Table 4). Rockfish abundance increased significantly with higher substratum relief: $0.2 \pm 0.1,0.5 \pm 0.2$ and $3.7 \pm 0.9$ ind. $100 \mathrm{~m}^{-2}$ on Snd, Agg and Bol, respectively (KruskalWallis test $\mathrm{p} \ll 0.01, \mathrm{n}=26$; significant difference between Snd \& Bol and Agg \& Bol). While rockfish abundance had a strong positive correlation with the percent area comprising Bol, the partial correlation matrix suggested this was due to covariance with other variables (Table 4). The biotope analyses (Fig. 5), when we controlled for the epifauna cover on each substratum type, supported the observed trends with higher substratum relief: thornyhead abundance did not show a consistent response while rockfish abundance increased.

\section{Epifauna effects on scorpaenid distribution}

\section{Epifauna cover}

Of the $\sim 122000 \mathrm{~m}^{2}$ of surveyed seafloor, $\sim 30 \%$ was bare of epifauna and $\sim 43 \%$ contained small epifaunal organisms; combined, these observations form our EA category at $\sim 73 \%$. Of the remainder with $\mathrm{EP}, \sim 11 \%$ was covered in $\mathrm{SSG}, \sim 15 \%$ in TSG and $<2 \%$ in $\mathrm{CS}$
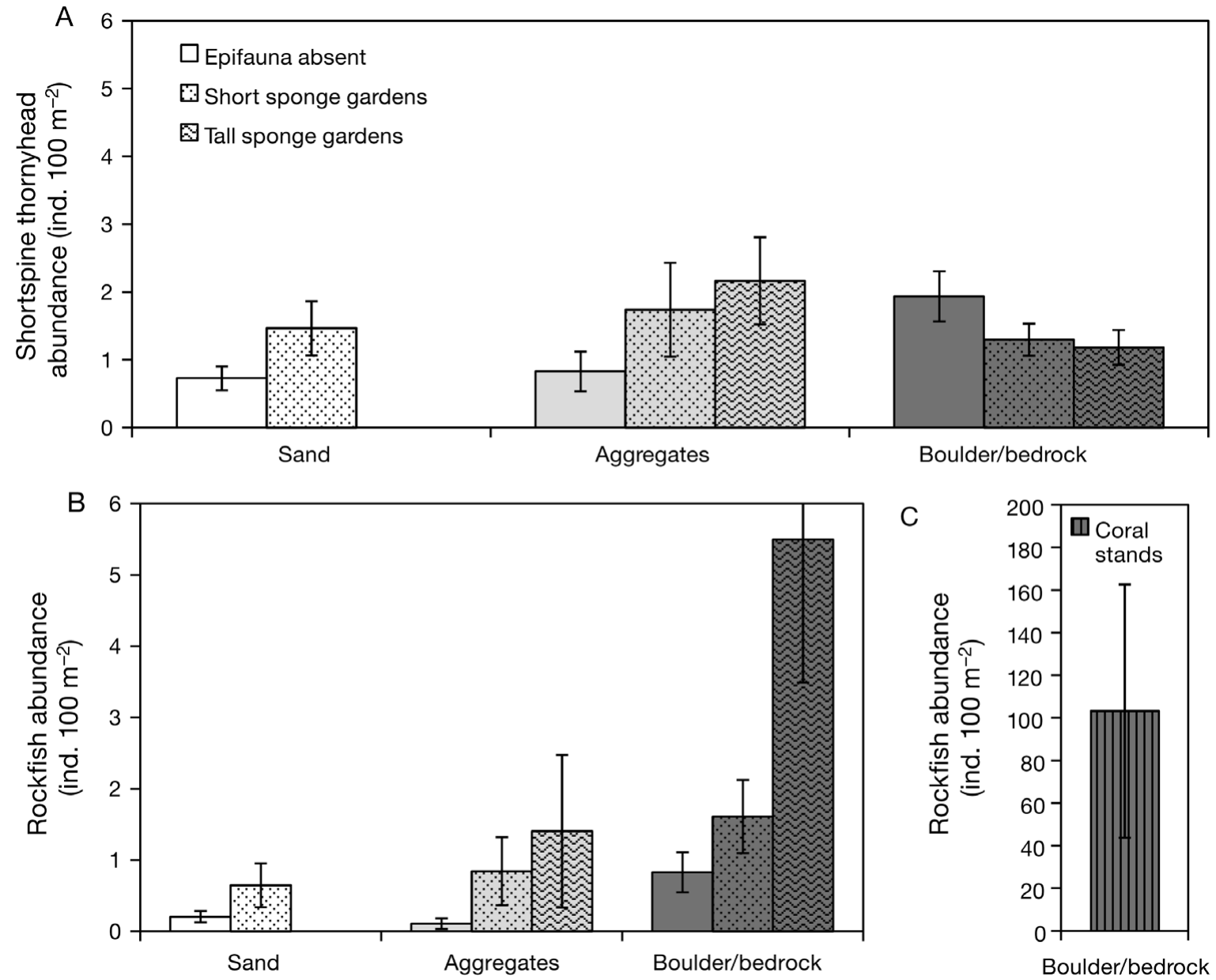

Substratum type

Fig. 5. Scorpaenid fish abundances in Learmonth Bank biotopes. (A) Thornyhead: abundances did not show consistent differences as substratum or epifauna relief increased. (B \& C) Rockfish: abundances were higher with higher substratum and epifauna relief, with a 2 order of magnitude increase in Coral stands on Boulder/bedrock 
(Table 2, Fig. 4). The abundances of sponge gardens and CS were lowest in the Basin and highest on the Bank (Table 1, Fig. 4). EP coverage had a strong negative partial correlation with depth and a strong positive correlation with the percent surface area comprising Bol, although the partial correlation indicated this was not a significant independent relationship (Table 4). Although the proportions varied among seascapes, each contained all 3 substratum types and all 4 epifauna cover categories (Table 1, Fig. 4). Some biotopes were rare: CS on Snd and on Agg only occurred in the Basin.

Thornyhead abundance varied slightly with epifauna cover: $0.9 \pm 0.2$ ind. $100 \mathrm{~m}^{-2}$ on EA seafloor, $1.4 \pm$ 0.3 and $1.3 \pm 0.2$ ind. $100 \mathrm{~m}^{-2}$ in SSG and TSG, respectively (Kruskal-Wallis test: $\mathrm{p}=0.01$; significant difference between EA \& SSG and EA \& TSG). The correlation matrix indicated a strong negative relationship between thornyhead abundance and EP coverage; however, the partial correlation suggests this is probably due in part to covariance with depth (Table 4). In general, thornyhead distribution reflected distribution of epifauna cover: $25 \%$ of these fish (339) occurred on bare substratum that represented $30 \%$ of the seafloor while $43 \%$ occurred on substratum that contained small epifaunal organisms, which was also $43 \%$ of our seafloor. In contrast, only $5 \%$ of all rockfish occurred on bare/ small epifauna while 95\% occurred on EP substrata, which only represented $27 \%$ of the surveyed seafloor (Fig. 4). See Fig. 3 for an example of such distributions along one transect. Rockfish abundance varied significantly with epifauna cover: $0.1 \pm$ 0.0 ind. $100 \mathrm{~m}^{-2}$ on EA seafloor, $1.0 \pm 0.2,4.1 \pm 1.1$ and $103.2 \pm 59.5$ ind. $100 \mathrm{~m}^{-2}$ in SSG, TSG and CS, respectively (Kruskal-Wallis test: $\mathrm{p} \ll 0.01$; all significantly different). Note that the majority of CS patches surveyed were much smaller than $100 \mathrm{~m}^{2}$ in size. The correlation matrix suggested a strong positive relation between rockfish abundance and EP coverage although significance is reduced in the partial correlation matrix (Table 4).

Stepwise multiple regressions for thornyhead and rockfish abundances, including all variables listed in Table 4, resulted in models that attributed the best covariance to linear relationships with single variables in both cases. The regression models were:

$$
\begin{gathered}
T=2.13 \cdot D-3.42, \quad \mathrm{r}^{2}=0.69 \\
R=0.762+5.61 \cdot \mathrm{EP}, \quad \mathrm{r}^{2}=0.77
\end{gathered}
$$

where $T$ is thornyhead abundance, $D$ is depth $(\mathrm{m}), R$ is rockfish abundance (ind. $100 \mathrm{~m}^{-2}$ ) and EP is Epifauna present (\%). Thornyhead abundance increased with depth and rockfish abundance increased with higher percent coverage of EP (SSG, TSG and CS). No interaction between the 2 fish groups emerged.
The only substratum type with all 4 epifauna cover categories in substantial abundances was Bol. Rockfish species richness was significantly higher in EP categories on Bol in comparison with EA on Bol (Kruskal-Wallis test: $\mathrm{p} \ll 0.01, \mathrm{n}=9$ ). Species richness, expressed as fish density, averaged $0.9 \pm 0.0$ ind. 100 $\mathrm{m}^{-2}$ on EA seafloor, $1.6 \pm 0.1,2.3 \pm 0.1$ and $2.0 \pm 0.2$ ind . $100 \mathrm{~m}^{-2}$ in SSG, TSG and CS, respectively. All scorpaenid species occurred at least once in sponge gardens in which sharpchin rockfish and rosethorn rockfish Sebastes helvomaculatus were the most frequent. All species, except bocaccio $S$. paucispinis, also occurred at least once in CS. A greater proportion of the larger rockfish species (rougheye rockfish $S$. aleutianus and shortraker rockfish $S$. borealis) were associated with CS compared with sponge gardens.

EA substrata had noticeably denser aggregations of benthic macrofauna in comparison with surrounding EA substrata. Macrofauna observed on EP substrata, other than scorpaenid fish, included crinoids Florometra sp., basket stars Gorgonocephalus eucnemis, octopus Octopus rubescens, hagfish Eptatretus stoutii, brittle stars, shrimps, crabs, squat lobsters, and hydroids. Macrofauna associated with Primnoa pacifica, but not sponges, included sea stars Hippasteria heathi, nudibranchs Tritonia diomedea, barnacles, anemones, skate eggs, sculpins, and a single golden king crab Lithodes aquaspina. These organisms did not appear to be obligate associates of sponges or corals and occurred elsewhere.

\section{Sponges}

The most abundant short sponge was Auletta sp. (new species, Demospongia; H. M. Reiswig pers. comm.) and the most abundant tall sponges were Acanthascus spp. (A. dawsoni, A. dowlingi, A. cactus and A. platei; Hexactinellida) and Aphrocallistes vastus (Hexactinellida). Other sponge species identified include 2 Hexactinellida, Farrea occa (Fig. 2B) and Heterochone calyx, and 2 Demospongia, Mycale bellabellensis and Poecillastra tenuilaminaris. SSG occurred on 13 of the 26 untrawled transects, while TSG occurred on 16 . When present on a transect, sponge gardens averaged $42.2 \pm 6.5 \%$ of the seafloor coverage. The majority of observed patches were $\sim 200 \mathrm{~m}$ in length, and the largest nearly continuous patch of sponge gardens stretched $>700 \mathrm{~m}$ along Transect $S$ (Figs. 1 \& 3); over one-third of all rockfish (573) observed were on this Moraine transect.

With the biotope comparative analyses (Fig. 5), we controlled for substratum type and quantified the independent effect of epifauna cover on scorpaenid abundance. Thornyhead abundance did not change consistently from EA seafloor to SSG and TSG. For the 
3 substratum types, thornyhead abundance was significantly higher in SSG compared with EA on Snd ( $t$-test: $\mathrm{p}=0.03, \mathrm{n}=8$ ), but did not differ among the 3 epifauna categories on Agg (Kruskal-Wallis test: $\mathrm{p}=0.4, \mathrm{n}=9$ ) or on Bol (ANOVA: $\mathrm{p}=0.17, \mathrm{n}=9$ ) (Fig. 5A).

Rockfish showed preference for TSG; $80 \%$ of rockfish observations were in the $14.6 \%$ of the seafloor covered in TSG. Within the biotope comparative analyses, rockfish abundance consistently increased with higher epifauna relief created by sponge gardens, independent of substratum type. From EA seafloor, the average rockfish abundance increased 4.2 times in SSG and 9.7 times in TSG. The differences among all 3 epifauna cover categories were significant on Bol (ANOVA: $\mathrm{p}<$ 0.03, $\mathrm{n}=8$ ) although not on Snd (Mann-Whitney $U$-test: $\mathrm{p}=0.74, \mathrm{n}=8$ ) or Agg (Kruskal-Wallis test: $\mathrm{p}=$ 0.07, n=9) (Fig. 5B).

\section{Coral}

Eight taxa of corals were present: Primnoa pacifica (Fig. 2C), Stylaster spp., Swiftia pacifica, Paragorgia sp., Pennatulacea, Scleractinia, and 2 unidentified soft corals. Stylaster spp. were the most abundant but they grow to only a few centimetres in height. Observations of the other corals were few, except for 750 encounters with $P$. pacifica.

Primnoa pacifica occurred exclusively anchored to hard substratum; both were most abundant on the Bank where the number of $P$. pacifica was positively correlated with the percent surface area comprising Bol (Spearman $r=0.80, p=0.02, n=8$ ). We encountered two-thirds of the $P$. pacifica on 2 Bank transects, $P 1$ and $P 2$, where the surveys were $\sim 50 \%$ Bol; 365 corals occurred on the $850 \mathrm{~m}$ long $P 1$ transect alone (Fig. 1). The CS category, at $1.6 \%$, was rare (Fig. 4) and scattered along 16 of the 26 transects with only a single occurrence on a trawled transect. Tall corals ( $\geq 30 \mathrm{~cm}$ in height) tended to occur in groups and the largest groupings were $\sim 2 \mathrm{~m}$ in height and $\sim 4 \mathrm{~m}$ in width on boulders of Basin transects. The largest patch of clustered CS stretched $\sim 200 \mathrm{~m}$ along a Bank transect ('P1' in Fig. 1), but most often patches were sparse and only a few metres in length. Over $50 \%$ of CS (at least 1 coral $\geq 30 \mathrm{~cm}$ height) had at least one rockfish associated with their structure, while no rockfish were associated with short corals (between 10 and $30 \mathrm{~cm}$ height).

\section{Bottom trawling effects on scorpaenid distribution}

Six Tr (Groups 1 and 2 in Fig. 1) and 6 UTr transects (' $U$ ' in Fig. 1) of similar characteristics were compared (Table 5). Trawl evidence ranged between 5 and 22 events per $\operatorname{Tr}$ transect and averaged $15 \pm 3$ events, while no trawl evidence occurred on any UTr transect (Table 5). No Primnoa pacifica was observed on boulders that had visual evidence of trawling and there was $\sim 13$ times less coral in the Tr transects than in the UTr, which was a significant difference (Table 5). Of the few corals within the Tr transects, $\sim 90 \%$ were short (between 10 and $30 \mathrm{~cm}$ in height), whereas within the UTr only $\sim 20 \%$ were this small size. Thornyhead abundance on the UTr transects was the same as on the Moraine, the seascape with the highest abundance of thornyhead (Mann-Whitney $U$-test: $\mathrm{p}=0.09, \mathrm{n}=7$ and 6; Tables 3 \& 4), whereas thornyhead abundance on the $\operatorname{Tr}$ transects was significantly higher (Table 5). Rockfish abundance was significantly lower on Tr transects, by 4 -fold (Table 5). No Tr transect rockfish occurred within CS while $33 \%$ of UTr transect rockfish were within CS (Table 5).

\section{DISCUSSION}

\section{Scorpaenids of Learmonth Bank}

Shortspine thornyhead and rockfish represented $78 \%$ of demersal fishes observed at Learmonth Bank; this assemblage is the most common commercial fish captured in similar habitats of Alaska (Heifetz 2002). The 2 scorpaenid genera have similar life history characteristics (Love et al. 2002) and there was no difference in their overall abundances, a similarity that made subsequent comparisons of the genera more robust. The overall thornyhead abundance of $1.1 \pm$ 0.2 ind. $100 \mathrm{~m}^{-2}$ is comparable with abundances in the Gulf of Alaska over a similar depth range (Else et al. 2002). The distribution of thornyhead over Learmonth Bank was random with relatively little variability among transects or among seascapes. Sightings were mostly of solitary individuals; the mechanisms for this behaviour might include reduction of intraspecific interaction in a species known to be cannibalistic (Love et al. 2002) or reduction of intraspecifc competition for resources. In contrast, rockfish distribution was clumped and abundances were higher on the Bank and Moraine where substratum was rougher. Learmonth Bank's rockfish assemblage comprised 9 species, a regional assemblage richness not uncommon on the northeast Pacific coast where there are nearly 100 known species of rockfish (Love et al. 2002).

\section{Benthic biotopes and scorpaenid associations}

Glaciation has created a diversity of seafloor habitats on and around Learmonth Bank. The seascapes sur- 
veyed varied from sandy plains of glacial till (majority), to a moraine of aggregated mixed sediments, to deeply incised bedrock. Scattered boulders added marked relief and were often colonised by large biogenic structures especially in the flat, sandy Basin, where Primnoa pacifica on boulders was the only large-scale relief. While each seascape had different degrees of representation by biotopes, most transects were a mosaic of all 12 biotopes. The patchiness of biotopes over a small scale (metres) facilitated observation of habitat use by scorpaenid fish.

Ocean waters off British Columbia generally support an abundance of sponges including glass sponges (Hexactinellida), possibly because of high dissolved silicate levels (Leys et al. 2004, Whitney et al. 2005). Learmonth Bank's sponge aggregations were encrusting on hard substrata where aggregations could be so dense they completely covered the seafloor; however, they did not form sponge reefs (sensu Cook et al. 2008). Similar sponge gardens occur along the British Columbia coast (Marliave et al. 2009). Sponges were observed on large cobbles while Primnoa pacifica exclusively anchored to boulders and bedrock. Large biogenic structures require sturdy, immobile substratum to persist, otherwise current forces can destabilize the entire structure (Tunnicliffe \& Syvitski 1983).

Overall, thornyhead were no more abundant when sponges were present than on the same substratum type with bare surfaces or those covered with small epifauna. Occurrence with Primnoa pacifica was too low to test for a difference, but numbers and observations suggest no apparent association. There is a likely relationship of thornyhead abundance with depth as seen in the Gulf of Alaska (Else et al. 2002). Else et al. (2002) also report a positive relationship between thornyhead and hard substratum, unlike Stein et al. (1992), Love et al. (2002), and the present study. The discrepancy may stem from inclusion of cobbles as hard substratum by Else et al. (2002). Thornyhead abundance patterns may also respond to prey distribution (authors' pers. obs.) and density-dependent negative feedback (Love et al. 2002).

Rockfish abundance was strongly related to the presence of sponge garden and CS coverage and rockfish were consistently more abundant on substrata covered in higher-relief epifauna. This rockfish study is the first to investigate abundance responses to both sponges and corals. Large sponges are emerging as major components of benthic habitat, from Washington State to Alaska (Campbell \& Simms 2009) yet their role as fish habitat is poorly studied, although 2 recent studies in British Columbia demonstrate higher rockfish abundances on large reefs of glass sponges (Cook et al. 2008, Marliave et al. 2009). Our work, however, records the important role of scattered sponges on hard substratum - a habitat much more abundant in coastal and shelf waters. Even dense stands of smaller sponges (10 to $50 \mathrm{~cm}$ in height) harbour an order of magnitude greater density of rockfish than do bare surfaces. Average rockfish species richness was double in sponge and coral biotopes, and similar to the higher diversity seen in undamaged versus trawled sponge reefs in Hecate Strait (Cook et al. 2008).

There is much attention paid to the role of corals like Primnoa pacifica in providing shelter for fish (e.g. Roberts et al. 2009). However, important fish habitats are those that support a significant percentage of the population at comparatively high densities (Auster 2005). Although rockfish density in coral biotopes was much higher than in sponge biotopes, $P$. pacifica was not abundant throughout the study area. TSG covered 10 times more surface area than CS and contained over 13 times the number of rockfish, i.e. $~ 80 \%$ of all observed rockfish. Similarly in the Gulf of Alaska, P. pacifica occurred on only $1 \%$ of boulders (Krieger \& Wing 2002). The limited cover by the coral biotopes reduced statistical power in our analyses of rockfish distributions. Compared with the Bank and Moraine, the apparent importance of corals in the Basin was higher; one-third of Basin rockfish were associated with P. pacifica, which only covered $0.1 \%$ of the surveyed Basin. Corals a couple metres high provided relief in the otherwise flat and uniform Basin. The Basin is where trawling has its greatest impact and these large gorgonian corals are the main bycatch of Learmonth Bank's trawl fishery (Ardron et al. 2007).

\section{Role of seafloor relief}

Proposed causes of rockfish attraction to biogenic structures from previous work include enhanced prey availability, shelter for predator avoidance and juvenile nursery areas (Fosså et al. 2000, Krieger \& Wing 2002, Auster 2007). These factors may be secondary effects of high relief and not unique to sponges and corals. For example, scorpaenid prey species (Love et al. 2002) observed on sponges and corals also occur throughout the surrounding area (Krieger \& Wing 2002, the present study). Through stomach content analyses, Husebø et al. (2002) found rockfish are not linked to coral sites through feeding habits and suggest the physical structure of corals attracts rockfish, rather than some biological attribute.

We used height in our classification scheme to determine the role of relief rather than just the identity of the biogenic structure. Over $50 \%$ of Primnoa pacifica taller than $30 \mathrm{~cm}$ had at least one associated rockfish and often several while, in comparison, not one rockfish was observed with $P$. pacifica under $30 \mathrm{~cm}$ in 
height. The same trend occurred with sponges: rockfish abundances were 4 times greater among tall (over $50 \mathrm{~cm}$ ) than short sponges. When we controlled for the presence of biogenic structures, increasing substratum relief (Snd to Agg to Bol) resulted in a similar increase in rockfish abundance. Likewise, a submersible study off the coast of Washington concluded that rockfish were 3 times more abundant in higher than in lower bottom relief habitat (Jagielo et al. 2003).

Learmonth Bank's scorpaenids have different morphologies and behaviour. Thornyhead feed on a wide variety of benthic prey, including shrimps, amphipods, zooplankton and small fish, and usually settle motionless on the seafloor (Else et al. 2002, Love et al. 2002) as we observed in nearly all our sightings; not once did a thornyhead occur within a sponge or coral. Dense aggregations of biogenic structures, as occurred on boulders and bedrock, may reduce available space for thornyhead. The thornyhead body has a flattened ventral surface, broad head, broad pectoral fins and a narrowed anterior, features that assist the fish to maintain position in bottom currents (Hoerner 1965, Webb 1989), while a low, flattened body form maintains the animal within the boundary layer (Arnold \& Weihs 1978). Unlike rockfish, the thornyhead has no swim bladder, an adaptation for buoyancy control in midwater; instead, the benthic position reduces energy expenditure (Fänge 1966). We suggest the morphology and behaviour of thornyhead allows it an energyefficient means to hold its station or position (stationhold) on the current-swept seafloor of Learmonth Bank independently of seeking the shelter created by seafloor structures, such as sponges and corals.

The rockfish of Learmonth Bank feed on similar prey items as the thornyhead but displayed a different behaviour: most were stationary against or within erect structures. Nearly all rockfish were associated with either sponge or coral biotopes that comprised only $27 \%$ of the surveyed seafloor. Other studies also record rockfish against or within sponges, corals and boulders (Krieger \& Ito 1999, Fosså as reported in Husebø et al. 2002, Krieger \& Wing 2002, Freese \& Wing 2003). Associating with tall biogenic structures might provide proximate flow refuge while feeding on advecting zooplankton above the substratum. Most rockfish over flat seafloor were passively moving with the current or actively swimming, which suggests these rockfish cannot station-hold on the currentswept seafloor of Learmonth Bank without seeking out shelter created by seafloor structures, such as sponges and corals.

The bottom currents on Learmonth Bank that maintain the sediment-free bare substrata preferred by sponges and corals also challenge rockfish to hold station. We suggest that, while rough bottom provides shelter to rockfish, the abrupt vertical relief created by tall sponges and corals is effective as refuge from currents; Auster (2007) also proposes this role for corals. Further work that incorporates current measurements, quantifies relief and observations of scorpaenid behaviour should provide further tests of these ideas.

\section{Effects of trawling}

A consequence of the natural distribution of substratum types on the seascapes is a fishing ground bias, as illustrated by the distribution of commercial trawl sets (Fig. 1). Nearly all the trawl sets are located in Snd biotopes of Learmonth Bank's Basin. Ground-contact trawlers avoid rough and rocky seafloors, like those on the Bank and Moraine, to reduce net ensnarement and gear damage (Sinclair et al. 2005). While we observed numerous trawling events, we have little evidence for frequency or timing of the observed incidence. Bottom currents and organism activity redistribute sediment and, over time, visual evidence of trawling activity fades, so our study may reflect relatively recent trawling activity on our transects. The distribution of the 2002 to 2007 commercial trawl sets (Fig. 1) illustrates the relative intensity of trawling around Learmonth Bank but only as the trawl start points. For the depth range of Learmonth Bank, the median length of a bottom trawl in British Columbia extends $10 \mathrm{~km}$ from the start point (Ardron et al. 2007) suggesting the affected area at Learmonth Bank is more extensive than we can demonstrate.

All scorpaenid species observed at Learmonth Bank are British Columbia commercial demersal fish. The shortspine thornyhead fishery is large and rapidly expanding (Love et al. 2002), and 95\% of British Columbia's total allowable shortspine thornyhead catch is allocated to the demersal fish trawling sector (Fisheries and Oceans Canada 2010). Thornyhead were the single most abundant scorpaenid species at Learmonth Bank and, within the trawlable habitat of the basin, their abundance was 7 times that of all rockfish species combined. Its abundance was also higher on the Tr than on UTr transects. Hixon \& Tissot (2007) report a similar observation on Oregon's continental shelf and suggest that mobile scavengers may aggregate along trawl-door tracks where high-intensity trawling can increase preferred prey (Engel \& Kvitek 1998). Unlike Hixon \& Tissot (2007), our study compared adjacent regions of similar depth and, thus, we have greater confidence that abundance differences were not confounded by depth effects.

The presence and abundance of short sponges and corals on $\operatorname{Tr}$ transects may relate to several factors. 
First, the Agg category was more abundant and small sponges colonised cobbles. Second, smaller epifauna may escape destruction by trawling. Third, damage may reduce the size of these structures: Primnoa pacifica can lose most of their branches after a single trawl tow (Krieger 2001) and both corals and sponges show damage in high-intensity trawled areas (Heifetz et al. 2009). A fourth possibility is recent recolonisation, as observed in the Gulf of Alaska for P. pacifica (Krieger 2001). Whatever the cause, these smaller biogenic structures attracted few rockfish, probably because size is an important factor. P. pacifica was exclusively anchored to hard substratum, but despite the similar availability of suitable substratum, UTr transects had 12 times the numbers of $P$. pacifica than did Tr transects. Thus, even if a trawled area has begun to recover, rockfish are unlikely to repopulate until biogenic structures reach a substantial size. Rockfish were found substantially less often on Tr transects, which is attributable to lack of appropriate sponges or corals. Thus, as in Norway (Husebø et al. 2002), rockfish catch sizes will remain low in trawled areas.

Auster (2005) suggests the resilience of rockfish populations to disturbance may be reduced in the absence of biogenic structures. Given their longevity and low reproductive rates rockfish species are particularly susceptible to population crashes (COSEWIC 2007, 2008). Over half the rockfish on the UTr Basin transects were rougheye rockfish and yelloweye rockfish Sebastes ruberrimus, 2 of the largest and slowest growing rockfish species (up to 205 and $120 \mathrm{yr}$, respectively); both species have 'special concern' status with fishing as an identified threat (COSEWIC 2007, 2008). Their presence in the Learmonth Bank area is probably because the untrawled basin area is under jurisdictional dispute.

By using high definition quality video from a ROV, we could detail spatial relationships of benthic species at a scale not ordinarily achieved; normally survey data are equivalent to the length of an entire transect. Scientific trawling is destructive and, although a basic technique in deep-sea biology (Roberts 2002), it is limited in sampling as it cannot tow on rough substratum (Sinclair et al. 2005). Such habitat bias reduces the validity of rockfish stock estimates and supports the need for visual surveys to conduct population studies (Jagielo et al. 2003). Learmonth Bank is a proposed coral-sponge protection area and this study implies there are ecological benefits of such closure. There are marked differences in distribution patterns and associations of 2 scorpaenid groups. The shortspine thornyhead would not be adversely affected by losses in biogenic structures such as sponges and corals and could even concentrate in areas of localized trawling or areas of low biogenic structure density. However, the conse- quence to rockfish of extensive sponge and coral loss, especially near the bank, would be reduced numbers for sustained periods.

Acknowledgements. We thank the field team for data collection and advice, especially J. Boutillier (Chief Scientist), J. Rose, E. Edinger and J. Chu. Personnel of the Canadian Scientific Submersible Facility and the CCGS 'John P. Tully' aided field operations. S. Leys and J. V. Barrie provided additional insight. Research is sponsored by the Natural Sciences and Engineering Research Council Canadian Healthy Oceans Network, a university-government partnership dedicated to biodiversity science for the sustainability of Canada's 3 oceans. Additional support was provided by a University of Victoria Fellowship to C. Du Preez and by Fisheries and Oceans Canada.

\section{LITERATURE CITED}

Allen LG, Pondella DJ II, Horn MH (eds) (2006) The ecology of marine fishes: California and adjacent waters. University of California Press, Los Angeles, CA

Andrews AH, Cordes EE, Mahoney MM, Munk K, Coale KH, Cailliet GM, Heifetz J (2002) Age, growth and radiometric age validation of a deep-sea, habitat-forming gorgonian (Primnoa resedaeformis) from the Gulf of Alaska. Hydrobiologia 471:101-110

Ardron JA, Jamieson GS, Hangaard D (2007) Spatial identification of closures to reduce the by-catch of corals and sponges in the groundfish trawl fishery, British Columbia, Canada. Bull Mar Sci 81:157-167

Arnold GP, Weihs D (1978) The hydrodynamics of rheotaxis in the plaice (Pleuronectes platessa). J Exp Biol 75:147-169

Auster PJ (2005) Are deep-water corals important habitats for fishes? In: Freiwald A, Roberts JM (eds) Cold-water corals and ecosystems. Springer-Verlag, Berlin, p 747-760

Auster PJ (2007) Linking deepwater corals and fish populations. In: George RY, Cairns SD (eds) Conservation and adaptive management of seamount and deep-sea coral ecosystems. Rosensteil School of Marine and Atmospheric Science, Miami, FL, p 93-99

Ballantyne VA, Foreman MGG, Crawford WR, Jacques R (1996) Three-dimensional model simulations for the north coast of British Columbia. Cont Shelf Res 16:1655-1682

Barrie JV, Conway KW (1999) Late quaternary glaciation and postglacial stratigraphy of the Northern Pacific margin of Canada. Quat Res 51:113-123

Barrie JV, Conway KW (2002) Contrasting glacial sedimentation processes and sea-level changes in two adjacent basins on the Pacific margin of Canada. In: Dowdeswell J, O'Cofaigh C (eds) Glacier-influenced sedimentation on high-latitude continental margins. Geol Soc Lond Spec Publ 203:181-194

Bone Q, Marshall NB (1982) Biology of fishes. Blackie, London Bornhold BD, Barrie JV (1991) Surficial sediments on the western Canadian continental shelf. Cont Shelf Res 11: 685-699

Campbell JS, Simms JM (2009) Status report on coral and sponge conservation in Canada. Fisheries and Oceans Canada, Ottawa. Available at: www.dfo-mpo.gc.ca/ oceans/publications/cs-ce-2009-eng.pdf

Cook SE, Conway KW, Burd B (2008) Status of the glass sponge reefs in the Georgia Basin. Mar Environ Res 66: S80-S86

COSEWIC (Committee on the Status of Endangered Wildlife in Canada) (2007) COSEWIC assessment and status report 
on the Rougheye Rockfish Sebastes sp. type I and Sebastes sp. type II in Canada. COSEWIC, Ottawa. Available at: http://dsp-psd.pwgsc.gc.ca/collection_2007/ec/ CW69-14-526-2007E.pdf

COSEWIC (Committee on the Status of Endangered Wildlife in Canada (2008) COSEWIC assessment and status report on the Yelloweye Rockfish Sebastes ruberrimus, Pacific Ocean inside water population and Pacific Ocean outside waters population, in Canada. COSEWIC, Ottawa. Available at: http://www.sararegistry.gc.ca/virtual_sara/files/ cosewic/sr_yelloweye_rockfish_0809_e.pdf

- Crawford RW, Greisman P (1987) Investigation of permanent eddies in Dixon Entrance, British Columbia. Cont Shelf Res 7:851-870

Else P, Haldorson L, Krieger K (2002) Shortspine thornyhead (Sebastolobus alascanus) abundance and habitat associations in the Gulf of Alaska. Fish Bull 100:193-199

Engel J, Kvitek R (1998) Effects of otter trawling on a benthic community in Monterey Bay National Marine Sanctuary. Conserv Biol 12:1204-1214

Fänge R (1966) Physiology of the swimbladder. Physiol Rev 46:299-322

Fisheries and Oceans Canada (2010) Pacific region integrated fisheries management plan: groundfish. Available at: http://www-ops2.pac.dfo-mpo.gc.ca/xnet/content/MPLANS/ plans11/2011\%20Groundfish\%20IFMP_Final_Complete.pdf

Fosså JH, Mortensen PB, Furevik DM (2000) Lophelia korallrev langs norskekysten forekomst og tilstand. Prosjektrapp Havforskningsinst, Bergen

Freese JL, Wing BL (2003) Juvenile red rockfish, Sebastes sp., associations with sponges in the Gulf of Alaska. Mar Fish Rev 65:38-42

Gray DH (1997) Canada's unresolved maritime boundaries. IBRU Boundary Security Bull Autumn 1997, p 61-71

Heifetz J (2002) Coral in Alaska: distribution, abundance, and species associations. Hydrobiologia 471:19-28

Heifetz J, Stone RP, Shotwell SK (2009) Damage and disturbance to coral and sponge habitat of the Aleutian Archipelago. Mar Ecol Prog Ser 397:295-303

Hixon MA, Tissot BN (2007) Comparison of trawled vs. untrawled mud seafloor assemblages of fishes and macroinvertebrates at Coquille Bank, Oregon. J Exp Mar Biol Ecol 344:23-34

Hoerner SF (1965) Fluid-dynamic drag. Hoerner Fluid Dynamics, Brick Town, NJ

Husebø A, Nøttestad L, Fosså JH, Furevik DM, Jørgensen SB (2002) Distribution and abundance of fish in deep-sea coral habitats. Hydrobiologia 471:91-99

Jagielo T, Hoffmann A, Tagart J, Zimmermann M (2003) Demersal groundfish densities in trawlable and untrawlable habitats off Washington: implications for the estimation of habitat bias in trawl surveys. Fish Bull 101: 545-565

Krieger KJ (2001) Coral (Primnoa) impacted by fishing gear in the Gulf of Alaska. In: Willison JHM, Hall J, Gass SE, Kenchington ELR, Butler M, Doherty P (eds) Proceedings of the 1st international symposium on deep-sea corals, Halifax, Nova Scotia, 30 July-2 August 2000. Ecology Action Centre, Dalhousie University and Nova Scotia Museum, Halifax, p 106-116

Krieger KJ, Ito DH (1999) Distribution and abundance of shortraker rockfish, Sebastes borealis, and rougheye rockfish, $S$. aleutianus, determined from a manned submersible. Fish Bull 97:264-272
Krieger KJ, Wing BL (2002) Megafauna associations with deepwater corals (Primnoa spp.) in the Gulf of Alaska. Hydrobiologia 471:83-90

Lamb A, Hanby BP (2005) Marine life of the Pacific Northwest: a photographic encyclopedia of invertebrates, seaweeds and selected fishes. Harbour Publishing, Madeira Park

> Leys SP, Wilson K, Holeton C, Reiswig HM, Austin WC, Tunnicliffe V (2004) Patterns of glass sponge (Porifera, Hexactinellida) distribution in coastal waters of British Columbia, Canada. Mar Ecol Prog Ser 283:133-149

Love MS, Yoklavich M, Thorsteinson L (2002) The rockfishes of the Northeast Pacific. University of California Press, Los Angeles, CA

> Marliave JB, Conway KW, Gibbs DM, Lamb A, Gibbs C (2009) Biodiversity and rockfish recruitment in sponge gardens and bioherms of southern British Columbia, Canada. Mar Biol 156:2247-2254

Morgan LE, Chuenpagdee R (2003) Shifting gears: addressing the collateral impacts of fishing methods in U.S. waters. Pew Science Series, Island Press Publication Services, Washington, DC

Pearcy WG, Stein DL, Hixon MA, Pikitch EK, Barss WH, Starr RM (1989) Submersible observations of deep-reef fishes of Heceta Bank, Oregon. Fish Bull 87:955-965

> Richards LJ (1986) Depth and habitat distribution of three species of rockfish (Sebastes) in British Columbia: observations from the submersible PISCES IV. Environ Biol Fishes 17:13-21

> Risk MJ, Heikoop JM, Snow MG, Beukens R (2002) Lifespans and growth patterns of two deep-sea corals: Primnoa resedaeformis and Desmophyllum cristagalli. Hydrobiologia 471:125-131

Roberts CM (2002) Deep impact: the rising toll of fishing in the deep sea. Trends Ecol Evol 17:242-245

Roberts JM, Wheeler A, Freiwald A, Cairns S (2009) Coldwater corals: the biology and geology of deep-sea coral habitats. Cambridge University Press, Leiden

Sameoto JA, Lawton P, Strong MB (2008) An approach to the development of a relational database and GIS applicable scheme for the analysis of video-based surveys of benthic habitats. Can Tech Rep Fish Aquat Sci 2818

Sinclair AF, Conway KW, Crawford WR (2005) Associations between bathymetric, geologic and oceanographic features and the distribution of the British Columbia bottom trawl fishery. ICES CM 2005/L:25 Available at: www.ices. dk/products/CMdocs/2005/L/L2505.pdf

Stein DL, Tissot BN, Hixon MA, Barss W (1992) Fish-habitat associations on a deep reef at the edge of the Oregon continental shelf. Fish Bull 90:540-551

Tunnicliffe V, Syvitski JPM (1983) An unusual mechanism of sediment transport. Limnol Oceanogr 28:564-568

Webb PW (1989) Station-holding by three species of benthic fishes. J Exp Biol 145:303-320

Whitney F, Conway K, Thomson R, Barrie V, Krautter M, Mungov G (2005) Oceanographic habitat of sponge reefs on the Western Canadian continental shelf. Cont Shelf Res 25:211-226

Yoklavich MM, Greene HG, Sullivan DE, Lea RN, Love MS (2000) Habitat associations of deep-water rockfishes in a submarine canyon: an example of a natural refuge. Fish Bull 98:625-641

Zacharias MA, Howes DE, Harper JR, Wainwright P (1998) The British Columbia marine ecosystem classification: rationale, development and verification. Coast Manag 26:105-124

Submitted: August 25, 2010; Accepted: December 20, 2010

Proofs received from author(s): March 2, 2011
Editorial responsibility: Charles Birkeland,

Honolulu, Hawaii, USA 